\title{
Marching Towards Kullman's Diner: Performing Transnational American Sites (of Memory) in Bavaria
}

\author{
Birgit M. Bauridl
}

\section{Introduction}

The arrival of the advance contingents of U.S. troops in Southern Germany in the spring of 1945 and the liberation of that part of Germany from the Nazi reign of terror marked the beginning of a highly complex, mutually enriching, and at times intricately conflicted history of German-American encounters in the fields of politics, social interaction, and cultural exchange. In the decades to follow, the German State of Bavaria_-immediately after World War II the larger part of the American military occupation zone in Germany-saw the emergence, institutionalization, and transformation of a wide array of sites of contact. Originally (at least supposedly) 'American,' these cultural, political, or physical spaces grew into increasingly transnational sites of cultural contact, memory, negotiation, and transfer. They testify to the continued usability of theoretical notions of contact zones, famously identified by Mary Louise Pratt in 1991 as "social spaces where cultures meet, clash, and grapple with each other, often in contexts of highly asymmetrical relations of power" (34). While Pratt pinpoints texts as platforms of negotiations emerging from contact zones, the German-American sites of encounter since World War II are not just metaphorical but actual, physical spaces of cultural contact and ensuing processes of cultural negotiation. Complex dynamics of exchange, transfer, and appropriation in these contact zones oftentimes blur, if not erase categorical lines between 'German' and 'American' or even local 'Bavarian' cultural phenomena into a transnational and transcultural haze. Is, for example, a German-American Volksfest on the grounds of a U.s. military base in the German State of Bavaria featuring beer, pretzels, barbecue, line dance, and Blasmusik German or American or Bavarian? Whose cultural and social practices and narratives are enacted and continued by an exhibit located in a rural Bavarian museum that functions as a site of memory for Elvis Presley's legacy? In what shapes do memories emerge in a space that is characterized by a history of American presence and institutions such as Amerika Häuser

(C) BIRGIT M. BAURIDL, 2018 | DOI 10.1163/9789004292017_012

This is an open access chapter distributed under the terms of the prevailing CC-BY-NC License at the time of publication. 
or U.s. military training facilities and during times of the supposedly global, contemporary phenomenon of Americanization?

In their introduction to their edited collection on Transnational Memory (2014), Chiara De Cesari and Ann Rigney postulate:

[T] he time is ripe to move memory studies itself beyond methodological nationalism. Globalized communication and time-space compression, post-coloniality, transnational capitalism, large-scale migration, and regional integration: all of these mean that national frames are no longer the self-evident ones they used to be in daily life and identity formations. As a result, the national has also ceased to be the inevitable or preeminent scale for the study of collective remembrance. By now, in the second decade of the twenty-first century, it has become a matter of urgency for scholars in the field of memory studies to develop new theoretical frameworks, invent new methodological tools, and identify new sites and archival resources for studying collective remembrance beyond the nation-state. (2; my emphasis)

This article engages in the approach to memory suggested by De Cesari and Rigney in multiple ways. First, it illuminates new sites - sites located outside the United States in Bavaria, Germany. Second, it participates in discourses of cultural memory as transnational memory by highlighting the transcultural and transnational nature of these sites. It draws attention to the multiple cultural appropriations between and beyond German and American. Above all, it is interested in new theoretical frameworks beyond traditional notions of the archive. Signifying on Diana Taylor's 2003 monograph, The Archive and the Repertoire: Performing Cultural Memory in the Americas, this article scrutinizes the diverse shapes transnational memory takes in Bavaria. These may range from 'permanent' archives of memory in the material form of museums or memorials to the 'performatic' forms of cultural memory, i.e. events such as celebrations and holidays or everyday cultural and social habits and practices.

In her groundbreaking monograph, Taylor initiates the closing of a gap in memory research when she highlights and insists on the impact of embodied forms of memory in her discussion of what she terms the repertoire. The performative dimensions of memory in the Schechnerian sense of effective and transformative character-i.e. memory comes into being by doing it-holds true for all shapes of memory. Yet Taylor's repertoire shifts the focus to behavioral, physical, corporeal, and, at least in their single appearance, ephemeral manifestations of cultural memory. Performatic phenomena constitute acts of memory; memory becomes performative. While Taylor emphasizes the mobility of memory to oscillate between archive and repertoire, two working 
concepts that are by no means defined by clear-cut boundaries, she nevertheless observes: "The rift, I submit, does not lie between the written and spoken word, but between the archive of supposedly enduring materials (i.e., texts, documents, buildings, bones) and the so-called ephemeral repertoire of embodied practice/knowledge (i.e., spoken language, dance, sports, ritual)" (19; emphasis in original). Taylor makes a strong point for the study of performance as a key source for the study of memory: "Recognizing performance as a valid focus of analysis contributes to our understanding of embodied practice as an episteme and a praxis, a way of knowing as well as a way of storing and transmitting cultural knowledge and identity" (278). She concludes that the "repertoire too, then, allows scholars to trace traditions and influences" (20).

Within the wider framework of Taylor's discussion of memory, this article traces both the archive and the repertoire of German-American transnational memories in Bavaria - and the blurry fields in between. Hence, the purpose of this article is twofold. First, it pursues a conceptual endeavor regarding the dimension, location, and shape of cultural memory. It proposes to view cultural memory as a transnational contact zone that may be situated outside of the Unites States. It argues that cultural memory may appear both in and especially beyond textual or material shapes and therefore suggests an approach to transnational memory as cultural performance. Second, to illustrate its conceptual claim, the article surveys and scrutinizes select examples located in the complex landscape of contemporary German-American memories in Bavaria.

\section{Transnationalizing Memory: German-American Sites in Bavaria}

Collective and cultural memory have frequently been defined as concepts that pertain to present-oriented processes of self-definition and identity-formation drawing on real, imagined, or constructed narratives of a common past of a particular cultural or national community. The German-American contact zones emerging in Bavaria after World War II are, however, characterized by the co-presence of multiple cultural and national groups that construct collective memory/ies of the past and perpetuate communal cultural memory/ ies into the future. These contact zones illustrate the need for changing conceptualizations of nationally located sites of memory as 'sites of transnational memories' or 'transnational sites of memory.'

Calls for a more transnational approach to memory are not fully new to American Studies, yet nevertheless relatively recent. Preceding De Cesari and Rigney's insistence on transnational conceptualizations of memory, already in 2008 Udo Hebel notes in his "Sites of Memory in U.S.-American Histories and 
Cultures": "The multiethnic and transnational histories of North America and the hemispheric, Atlantic, and Pacific contexts of North American cultures have always given national U.s.-American sites and ceremonies of commemoration a multidirectional, pluralistic dimension-notwithstanding all historical processes and official acts of repression, exclusion, erasure, and forgetting" (57). Implicitly, Hebel points to the transnational and transcultural scopes and meanings which cultures of memory can assume within the United States. ${ }^{1}$ More explicitly, Hebel states in his epilogue "Whereto American(ist) Memory Studies?" to Hans-Jürgen Grabbe and Sabine Schindler's edited collection on The Merits of Memory: Concepts, Context, Debates:

As far as American(ist) memory studies are concerned, it seems that a creative synthesis of two recent turns, i.e. the transnational turn and the spatial turn, offers particularly promising perspectives for grounding American memory studies in the increasingly complex and challenging landscapes, structure, and processes of transnational exchange, competition, and conflict. Especially in transnational-or transnationally relevant or transnationally charged-spaces, memory will continue to be considered and interpreted as a shaping factor in acts of political legitimization and cultural opposition. (395)

In 2009, Hebel continues to urge: "transnational trajectories, implications, and politics of U.S.-American cultures of memories and sites of commemoration deserve more attention" (Hebel, "Introduction" 2). ${ }^{2}$

The German-American contact zones in Bavaria after World War II and the sites and processes of memory located in them make it necessary to engage in the debate on transnational memories. They also require a shift in focus from transnational sites of American memories situated within the United States to sites outside the United States. A "transnational approach directs attention to all kinds of 'sustained, cross-borders relationships spanning nation states' and to those phenomena not neatly captured within the borders of the latter" (De Cesari and Rigney 5; my emphasis). American memories and transnational processes of memory that relate to the United States can and must also be studied in non-U.s. locations that take the shape of contact zones involving American cultural and social participation. Since the end of World War II, the German State of Bavaria has been an increasingly transnational contact zone

1 For a discussion of transculturality, see Welsch; Lenz.

2 Also see Rothberg, who makes a similar point and "rethink[s] the conceptualization of collective memory in multicultural and transnational contexts" (21). 
full of crossroads of and for German American encounters of different politi$\mathrm{cal}$, social, and cultural manifestations and implications. From the liberation of the Nazi concentration camps in the spring of $1945^{3}$ to the ongoing presence of U.s. troops and their families especially in and around the Upper Palatinate community of Grafenwöhr, the U.s. military has been a momentous political, economic, and cultural force in a region paradigmatically stretched out between traditionalism and (post)modernization. Once-powerful American platforms of reeducation such as the Amerika Häuser have long since been closed down and turned into sites of memory of their own historical and cultural mission intricately embedded in cityscape ensembles of conflicted histories of a larger scale.

In different ways and to different extents over the course of the past decades, icons of 'American' (popular) culture such as cowboys, baseball, and diners have become part of 'German' leisure time activities. Annual German-American Volksfeste (fig. 1)strategically hosted within the otherwise sealed-off confines of military training areas have brought together, at times in astounding constellations and performances, internationally deployed U.s. troops and their dependents as well as the local population of the Upper Palatinate and their tourist guests. Local museums have staged Elvis Presley exhibitions documenting the King's military tour of duty in the area in the late 195 os as well as his popular culture outreach and personal legacy (fig. 2). And the small Upper Palatinate town of Oberviechtach has recently erected the only 9/1 1 memorial in Germany with an original wTC steel beam at its commemorative center (fig. 3).

A list of Bavarian transnational sites of memory including American and German participation can hardly be complete. Among its vast array of various shapes of memory, it includes material, physical sites established as quasiarchives for the purpose of commemorating contacts from confrontations to liberation in times of war and victory, for instance the Concentration Camp Memorial Site and Museum Flossenbürg (KZ-Gedenkstätte Flossenbürg; (fig. 4)), the Concentration Camp Memorial Site and Museum Dachau (KZ-Gedenkstätte Dachau), or the Nuremberg War Criminals Court (Reichsparteitagsgelände). These sites are reminders of public diplomacy and cultural exchange from reeducation and the Cold War to post-9/11, for example the Amerika Haus in Munich, the (former) German American Institute (DAI) in Regensburg, or the DAI in Nuremberg. They function as archives of the narrative of the U.S. military as well as its political and cultural presence in Bavaria, for instance the Grafenwöhr Cultural and Military Museum (Kultur- und Militärmuseum Grafenwöhr) or the 2012 Elvis Presley exhibit in the local museum of

3 Also see Gessner, "Dachau." 
Burglengenfeld, which was dedicated to Elvis's time as a soldier in training in Grafenwöhr. The 9/11 Memorial in the rural town of Oberviechtach is a similarly material site of memory. Yet its dedication ceremony in 2011 points to dynamics and dimensions of memory that go beyond permanent, material features and are characterized by their performatic, if not theatrical appearance. Similarly, the joint German and American Grafenwöhr Training Area Centennial celebration or the Veterans' Day celebrations by the U.s. Army in Grafenwöhr are further examples of the eventful and non-material, yet corporeal and ephemeral character of commemorative cultural phenomena of the German-American contact zone of Bavaria. Pullman City, as the adventure park's website describes it, is a "living Western town'" where "children and adults have been experiencing the Lower Bavarian 'Wild West' since 1997during archery, gold panning, pony and Western horse riding, with live country music, line dance and the romance of the campfire" (Pullman City). Last but not least, everyday German-American life/lives and their practices and habits, in the particular context of the former American occupation zone and the continued American presence, serve as constant transmitters and perpetuatorsas agents of memory - of American culture(s): diners such as Regensburg's Kullman's Diner or Max \& Muh Diner, Regensburg's Baseball Club "Buchbinder Legionäre," or the city's Cowboy Club.

\section{Deep Space-The Grafenwöhr Training Area}

Transcultural and transnational approaches to memory "take on board the principle that memory 'travels' " (De Cesari and Rigney 4). The list of examples above demonstrates that, with the continued presence of U.s. Armed Forces and civilians in Bavaria during the occupation and afterwards, Americans and American memories traveled to the German space. The Grafenwöhr Training Area may serve as a suitable example here. Located in the Upper Palatinate region of Bavaria, it has always been shaped by diverse presences. The military center of the German-American encounters in Graf, the American nickname for the Grafenwöhr Training Area, is the largest and most advanced military facility owned by the U.s. $7^{\text {th }}$ Army in Europe. Yet the first shot was not, as one might expect, fired by the U.s. Army after World War II or during the times of the occupation. Rather, it was fired by the Bavarian Army's 21-year-old cannoneer Michael Kugler in 1910 from Gruenhund Hill, now the area of the 7 th U.s. Army's Joint Multinational Training Command's Shooting Range 114. The GTA is shaped by multiple palimpsestic layers created by diverse groups present in the past-diverse cultures, imaginaries, and memories ranging 
from the Bavarian Army and Upper Palatinate villages to the Nazi era to postWwII Us occupation to the contemporary multinational structure led by the United States. Layer over layer, new histories and with them new memories are inscribed into the Bavarian landscape. These layers are, on the one hand, characterized by the respective synchronic transnational mobilities, especially American mobilities that continue to reach the Bavarian space since wwII. On the other hand, the present is shaped by the multiple layers of the past.

The German-American contact zone of Bavaria becomes a "deep space"-a phrase and concept I use elsewhere (Bauridl, "From Grafenwoehr to 'Graf'") in reference to Shelley Fisher Fishkin's idea of the deep map. In her response to Fishkin's idea, Karen Bishop explains the nature of scholarly deep maps as "open-access digital archives that collect all manner of multilinguistic primary and secondary text, paratext, ephemera, oral and written history, critical studies, and interdisciplinary and mixed media - to name just a few possibilities-in a series of overlaying and overlapping palimpsests built on a specific geolocation manifest on the surface of a digital map that serves as gateway to the archive" (2). Deep maps are interactive, digital maps that connect people, material artefacts, texts, experiences, memories, and narratives-which may constitute "conflicting interpretations" - to "the location that produced" them (Fishkin, "Deep Maps" 3). They emphasize ideas, stories, and people that "cross borders" (Fishkin, "Deep Maps" 3) and thus depict networks of past and present traces of individual and collective mobility within and outside the nation. Similarly, De Cesari and Rigney point to the idea of different memories intersecting and interacting in one particular space: "The transnational optics adopted in this volume allows memory to be visualized differently: not as a horizontal spread or as points or regions on a map but as a dynamic operating at multiple, interlocking scales and involving conduits, intersections, circuits, and articulations" (6). Approaching Bavaria as a German-American contact zone established by the end of WwII via the concept of the deep map/space means viewing the region not as a digital representation but as a physical and cultural network of memories, as a landscape shaped by transnational trajectories of - themselves heterogeneous-German and American memories. These diverse layers produce diverse memories in the present which are nevertheless located in the simultaneity of one space; they intersect, interact, negotiate their presence, are appropriated, and oftentimes become transnationally entangled.

The 2010 Centennial Celebration in Grafenwöhr clearly commemorates the initiation of the training area by the Bavarian Army; yet the celebration is staged by both the U.s. Army, now training on the former Bavarian grounds, and the German Bundeswehr. One of the highlights of the Centennial nevertheless serves as a perpetuation of U.S. national memories and narratives 
when a U.s. Veterans' Day celebration, broadcast by the U.s. station ESPN to the United States live from Germany, stages U.S.-American soldiers in a Warrior Challenge as strong, brave, and excelling national heroes. The visual dimension of the broadcast inevitably also includes the material and cultural space of the setting: Grafenwöhr and its historic water tower. Built in 1911 in Frankonian timber-frame design, the tower prefigures the post-wwiI American presence; at the same time it has become a visual symbol of the American (military) presence at the GTA ever since the occupation. Recognized by both German and American 'locals' as a symbol for the GTA, it constitutes a site of memory that fuses a Bavarian and an American past and present. The example highlights two intersecting characteristics of transnational memory/ies: firstly, 'national' memories continue to play a role but become transnationally blurred and entangled; secondly, the site as a deep space, i.e. the setting of memory-not to be confused with Pierre Nora's concept of the site of memory-interacts with and shapes memory.

\section{Transnational Appropriations: Elvis in Burglengenfeld}

The example of the Grafenwöhr Training Area implies that especially transnational sites of memory are inherently contested sites, i.e. they constitute 'usable' sites of appropriation which become utilized for diverse enactments of memory. They make visible the co-existence and the tensions between multiple national, sub-national, and super-national discourses. Together with scholars such as Bryce Traister or Shelley Fisher Fishkin (see esp. "Crossroads" 24), Heinz Ickstadt cautions American Studies to not all too enthusiastically engage in all-transnational discourses, over-looking the continued impact of national dynamics:

Between the local and the global there is still the 'national' as a category requiring continuous analysis. [...] [The] United States must be studied as a distinctive collective entity (however heterogeneous or divided it may perceive itself to be) within a network of global or transnational interrelatedness. (551)

Discussions of transnational memory are fully in sync with transnational American Studies at this point. De Cesari and Rigney likewise note that "the transnational dynamics of memory production operate in conjunction with the continuous presence and agency of the national"; national and transnational memories "remain deeply entangled" (6). In 2012, a local Bavarian 
museum in Burglengenfeld on the occasion of the 35th anniversary of Elvis's death hosted an exhibit commemorating not Elvis Presley per se, but, more particularly, the most prominent GI's presence in the Upper Palatinate (fig. 2). As a site of negotiation between sub-national, national, and ultimately transnational discourses of memory, this exhibit visualized how this particular German region has appropriated Elvis in its collective memory as a symbol for the American presence and for a definition of the region's (rather than Germany's) cultural space and collective identity, a definition which reflects the region's own role and format as a cultural contact zone. The exhibit allowed locals and visitors to tour a temporally and spatially condensed version of this area and era of encounter and of its cultural and political negotiations. Elvis was in Germany for 17 months, starting with his arrival on October 1, 1958. Strikingly, Elvis was not stationed in the Upper Palatinate, but in the Hessian Friedberg. Nevertheless, he spent several weeks in the Grafenwöhr area for military training. In large parts of the exhibit, Elvis is less a GI in the Cold War than a visitor to the Upper Palatinate whose identity stands in reciprocal transfer with that of the region. When the visuals in the exhibit portray Elvis as immersed in American master narratives and as the prototypical Franklinian self-made man, as the son who takes care of his family, as the ideal son-in-law, and as an American, hard-working, masculine, strong hero, who preferred to fully engage in his military duties rather than accept any more convenient options offered to him as a 'star,' they define Elvis as an ideal character. Despite all American connotations, this ideal character type is also a local Upper Palatinate one, and his portrayal is not only a characterization of the GI but also of the allegedly archetypal Upper Palatinate self. Thus, an exemplary and prominent photograph of Elvis shows him dapper and well-groomed, clad in a woolen cardigan, flouncy shirt, and a slim tie fit for a local Sunday coffee gathering with the future mother-in-law: "schwiegermuttertauglich" reads the German caption to the photograph. The exhibit thus entangles and confuses national and regional processes of remembering and consequential self-construction into a transnational haze. In the contact zone, national (in this case U.s.) memories are appropriated and adapted and become part of national (German / Bavarian) memories and thus transnationally entangled. Likewise De Cesari and Rigney portray "cultural remembrance" as "involve[ing] the continual production, remediation, and sharing of stories about a past that changes in relation to the new possibilities for interpreting it within shifting social frames operating at different scales and across different territories (see Erll and Rigney 2009)" (8).

The example of the exhibit, like the example of the GTA's Veterans' Day, elucidates the significance of the site in which memorial processes take place. 
Like Halbwachs's cadres sociaux de la mémoire, 'site' here includes more than the physical geography of the particular space. It is the social, cultural, and political space that influences and impacts processes of memory. In the German-American contact zone the memory of an American citizen, Elvis Presley, is staged in the social, cultural, and political space of another nationmore precisely, of a particular region of another nation. It is the present needs of that region - a desire to stage its regional identity as individual and visible within the national framework, a longing to enact its own cosmopolitanism as opposed to a past existence as the margin of the nation - that become entangled with the imagined past of the U.s. celebrity. The commemoration of Elvis becomes transnational; or, seen from the flipside of the coin, German memory becomes transnational by appropriating the American Elvis.

The exhibit merges multiple angles and spatial levels of communal identity with larger historical patterns when it constructs an emancipated relationship between 'Americans,' 'Germans,' and the Upper Palatinate during the Cold War. It emphasizes Elvis's close-knit relationship with the local community as well as with the international military activities he was involved in. It construes his presence at a time of containment of the East and integration of Germany as a time in which the local space participated in (American) Cold War activities as an equal and empowered global player rather than as an occupied post-war region. Elvis participated in Winter-Shield, a NATO maneuver and an activity in the Cold War context conducted by the us and the German military. While the photographs, taken in this context, of Elvis with Upper Palatinate women or soldiers visualize the close-knit relationship between Elvis and the region and are thus more an expression of a regional taking-possession of the GI than of military activities, the presence of the German soldiers stationed in the Upper Palatinate nevertheless demonstrates the military and physical power of the region as an important contributor to the transnational Cold War endeavor. In the exhibit, Winter-Shield, a NATO maneuver, is a performance and self-enactment of the military, political, and international impact of the Upper Palatinate. It helps to display the region as a space of inter/transnational influence, power, and protection. If this Elvis can be appropriated and integrated into an Upper Palatinate context, with the region and its inhabitants as active agents in this very process, Elvis is turned into an icon of one's own empowerment.

The example of Elvis in Burglengenfeld shows that memory in transnational spaces is not either or, but rather an ever-evolving fusion and negotiation. It is what Rothberg terms 'multidirectional memory': "Against the framework that understands collective memory as competitive memory-as a zerosum struggle over scarce resources-I suggest that we consider memory as 
multidirectional: as subject to ongoing negotiation, cross-referencing, and borrowing $[\ldots]$ " (3; emphasis in original). Rothberg adds:

I have proposed the concept of multidirectional memory which is meant to draw attention to the dynamic transfers that take place between diverse places and times during the act of remembrance. [...] The model of multidirectional memory posits collective memory as partially disengaged from exclusive versions of cultural identity and acknowledges how remembrance both cuts across and binds together diverse spatial, temporal, and cultural sites. (11)

Likewise, "dynamic transfers" happen between the American Elvis of the late 1950s, the German region of the 1950s, and the German region of the early 21st century; Elvis's commemoration links and entangles the United States and Germany and thereby becomes a memory not just of Elvis and the U.s. but also a memory and construction of the Bavarian German self. The German selfconstruction - like cultural memories according to De Cesari and Rigneyis "[...] made up of heterogeneous elements, borrowings, and appropriations from other languages and memorial traditions that are assembled together into narratives" (15).

\section{Towards Transangular Perspectives: Commemorating 9/11 in Bavaria}

Seen from the perspective of 'American' memory/ies, the Elvis exhibit, as one of the example(s) of the contact zone, demonstrates that 'American' memory/ies become transnational in their outlook and appropriation. In "Towards a Prismatic American Studies," a programmatic article in the conceptual context of transnational American Studies, Jane Desmond insists on an understanding of the United States as an "interlocking set of imaginaries." These imaginaries may be situated and brought about by agents in- or outside the United States; they are always related to both, the United States and the spatial contexts in which they are produced. Memories produced in the German-American contact zone in Bavaria constitute a part of the imaginaries that shape our understanding of the United States. In Desmond's call for "prismatic American Studies," the notion of the "prismatic" stresses the multiple and "interlocking" understandings of the U.s., "the multiple coexisting illuminations coming from different angles" — and I would add spaces_- "of vision" (6). 
Yet do the multiple national, sub-national, and super-national discourses remain clearly distinguishable? In other words: Can transnational memory be pieced together like a puzzle consisting of clearly identifiable components of diverse national, sub-national, or super-national discourses? Desmond's "prismatic" perspective metaphorically stresses triangular approaches to the transnational. The triangular highlights that 'transnational' in its real-life material, discursive, and ideological dimensions means more than bilateral or bidirectional relationships between clearly defined agents, groups, and entities. Transnational American Studies, then, needs to denote more than comparative approaches or discussions of two-polar interactions. As the multidirectional memory/ies in the German-American contact zone show, more than two agents and perspectives are involved in transnational processes. These agents and perspectives are different in reference to diverse national, cultural, social groups, to diverse time frames, to diverse spaces that shape them. Moreover, once they enter transnational processes and interaction, they do not stay the same or clearly distinguishable from each other; they become entangled into a complex transnational network of (ex)changes and intersections. Consequently, the negotiations and memories located in this contact zone require neither a comparative nor an additive, but a connective or, rather, integrative perspective. This perspective needs to be based on the concept of the transnational; it needs to emphasize the involvement of multiple parties, which do not simply add up into a compound, but which become increasingly entangled and blurred. "Transangular" as a conceptual and methodological metaphor stresses the recognition of "more complicated trajectories than simply triple comparisons"; it highlights the "possibly infinite interconnectedness of all angles into palimpsestic structures"; and ultimately it calls for a likewise "transangular mode of investigation" (Bauridl and Hebel 457).

The example of the Oberviechtach 9/11 Memorial (fig. 3) reflects the nexus between memory/ies and spaces and the need for a transangular perspective most immediately. Dedicated in October 2011, the memorial situated in the middle of the small Upper Palatinate town of Oberviechtach includes the only original steel fragment from the ruins of the WTC on display in Germany, if not in Europe. Oberviechtach is located 30 to 40 minutes away from the military bases and training areas of Grafenwöhr from which a considerable part of the U.s. American 'war on terror' was waged after the terrorist attacks of September 11, 2001. For decades, the local population had been in close contact with the American military and their families, with a large part of the local and regional economy profiting from the presence of the U.S. and the extensive investments of the military from the times of the Cold War through the beginning of the 21st century. Consequently, 
long-standing personal relations - in this case between the fire departments of Oberviechtach and New York City—led to the idea of a 9/11 memorial and eventually to the transatlantic mobility of a fragment of a WTC steel beam. ${ }^{4}$ The whole story is much more complicated and entails, among other things, the visit of a local theater group to New York City and alike ventures on both sides of the Atlantic. The memorial itself is a relatively modest structure which gains additional interpretative and ideological significance because of its on-site proximity to the local monuments remembering the German dead of wwI and wwII. Although the performative pomp and circumstance of the dedication ceremony in October 2011 seems to have remained a singular event in the still brief history of the memorial, the site itself presents a particularly multivocal crossroads of transnational histories and narratives in a place surrounded by the local amenities and needs of a gas station, a newsstand, and a parking lot.

At the Oberviechtach 9/11 memorial, at first sight several incongruent 'parts' are juxtaposed and fused. Is the memorial an American site of memory in a German space? Is it a German (self-)construction, similar to the Elvis exhibit in Burglengenfeld, that appropriates the memorial, and thus a terrorist attack far away, as an occasion to demonstrate one's own outstanding position as the only place in Germany to host a steel fragment from the terror-struck site? Is the memorial an American site in Germany that elevates American memory into an all-encompassing, city-upon-the-hill realm? Is it a removed site of American grief, of American power, or of local German everyday life? Does the site commemorate 2001 and the American tragedy of $9 / 11$, and the local WWI and WWII memorials happen to be nearby; or is the $9 / 11$ memorial located in a site that primarily commemorates the local experience of WwI and wwII? ${ }^{5}$ As a phenomenon of the contact zone and seen in the particular historical and present context of German-American encounters in Bavaria, the site is all of that at once and none of its specific components alone. At first sight dedicated to the commemoration of the tragedy of one event, the site becomes a transangular constellation of multiple and multidirectional memories.

4 See Gessner, "Remembering 9/11."

5 The question “Does the memorial's slogan 'dedicated to all who serve with honor' pertain to the local Oberviechtach or New York City firefighters or does it extend to the wwI and WWII memorials nearby?" contributes to the complexity of the site and would require a separate and more far-reaching critical discussion of implied comparisons, evaluations, or even simplistic appropriations. 


\section{Encounters of a Different Kind: Flossenbürg Concentration Camp Memorial Site and Museum}

The most obvious site of memory of American encounters in the GermanAmerican contact zone of Bavaria is also possibly the most complicated one: the Flossenbürg Concentration Camp Memorial Site and Museum (fig. 4). When U.s. troops liberated the Nazi concentration camp of Flossenbürg in the Upper Palatinate close to today's German-Czech border, they encountered the horrible scenes that the Allied Forces in the West and the Red Army in the East had already been confronted with across Germany and Europe and which they would be confronted with again in the muchbetter known Dachau concentration camp some 200 kilometers further south and close to Munich. Flossenbürg had been a Nazi concentration camp throughout the war supplying the Regensburg Messerschmidt airplane factory with workers and-significant for current perceptions of the site-serving as a prison site for Hitler's so-called 'special personal prisoners,' among them theologian Dietrich Bonhoeffer. Although it took a while until Flossenbürg was given due attention as a site of national remembrance and mourning - to some extent because of the world-wide recognition of Dachau and because of its own remote location only a few miles away from the former Iron Curtain running through the seemingly impenetrable Bavarian and Bohemian Forests-it has now become a very visible part of the Bavarian State Foundation for Commemoration. What is particularly interesting about Flossenbürg is its ever-increasing commemorative recognition outside of Germany as the place where Dietrich Bonhoeffer spent his last days, wrote some of his famous prayers, and was executed only a few days before the U.s. troops liberated the camp.

Flossenbürg constitutes a site of American encounters in three dimensions: liberation; U.s. visits from the nearby Grafenwöhr Training Area; and commemorative events including both liberators and liberated. Yet the spatial site of Flossenbürg is more complex, more multidirectional, and more transangular than that. Flossenbürg not only offers extended educational programs, guided tours, and special exhibitions, but it is also, and increasingly so, becoming a crossroads of memory for German, American, and European visitors. Official booklets describe Flossenbürg as a "European site of memory"-a description that bears adequate witness to the sufferings of the prisoners from all across Europe at the hands of the German and partly (East) European guards and executioners. Like all former concentration camps, Flossenbürg is also visited regularly by survivors who at times still join with their liberators from the U.s. forces-a commemorative 
practice that will soon cease to exist. After its liberation, Flossenbürg was used as a camp for prisoners of war and from April 1946 onwards as a camp for Displaced Persons. Displaced Persons from Poland launched the very first initiative to turn Flossenbürg into a site of memory. Besides the cemeteries in the town of Flossenbürg that continue to serve as a reminder of the cruelties committed at Flossenbürg, a particular memorial (which also reflects the cultural and religious impact of its predominantly Catholic Polish initiators) was added to the Flossenbürg concentration camp site: a church built of the material of the former concentration camp towers. Stadtbaumeister Linhardt drafted the commemorative, park-like-structured Tal des Todes, which stretches between the crematorium and the slightly-and symbolically-elevated church. In the 1950s, the (former barrack) area adjacent to the concentration camp's Appellplatz became a designated housing and homeowners' area for Displaced Persons. The rural homeowner's neighborhood continues to exist until today. The museum website consciously highlights the multidimensional use of the space: "Als anlässlich des $5^{\circ}$. Jahrestages der Befreiung des Kz Flossenbürg mehrere hundert ehemalige Häftlinge an ihren früheren Leidensort zurückkehrten, fanden sie auf dem ehemaligen Kz-Areal eine Wohnsiedlung, einen Industriebetrieb und einen als Parkanlage gepflegten Friedhof vor" (Skriebeleit, "Konzentrationslager Flossenbürg"). ${ }^{6}$ The industrial buildings were torn down in 2000; currently, the previous structures are turned into a more obvious and carefully crafted site of memory. Yet still today, the descendants of the former Displaced Persons literally cross the concentration camp site on their everyday route into the small downtown of Flossenbürg or on their way to work, possibly also in any of the infrastructural facilities of the Grafenwöhr U.s. military training installation. It is their presence and their story that best shows the multiple cultural and national, the transangular, dimensions of the site of Flossenbürg, liberated by the U.s. Army but crossed by many paths. ${ }^{7}$

6 When several hundred former prisoners returned to their former place of suffering for the 5 oth anniversary of the liberation of the Flossenbürg Concentration Camp, they encountered a residential area, an industrial plant, and a park-like cemetery on the former Concentration Camp grounds.

7 For a detailed study of the history of the Flossenbürg Concentration Camp as well as the memory work of the Memorial Site and Museum, see Skriebeleit's Erinnerungsort Flossenbürg. 


\section{Beyond the Archive}

The Flossenbürg Concentration Camp Memorial and Museum, in the sense of Taylor's archive, is made of "supposedly enduring materials (i.e., texts, documents, buildings, bones)" (19). Yet its commemorative practices-'events' with survivors, witnesses, liberators - point to a less stable and more performatic dimension of memory. This dimension may range from clearly keyed and framed events-i.e. events that are designated and recognizable as particular acts of commemoration and perpetuation and clearly marked in terms of time frame, site of performance, and purpose - to practices, behaviors, and habits that are either less keyed and framed - or not at all. These dimensions of memory are less studied than the archival dimensions.

Astrid Erll notes in her introduction to Cultural Memory Studies: "The field thus remains open for the exploration of unintentional and implicit ways of cultural remembering [...] or of inherently non-narrative, for example visual or bodily, forms of memory" (2). In "Sites of Memory in U.S.-American Histories and Cultures," Hebel emphasizes the importance of "commemorative performances" (53) already in the early republic "for the affirmation of the newly created collective identity" (53). He observes that a "large variety of local, regional, and national festivities that took the scripts and repertoires of traditional religious and folk rituals" was appropriated and adapted to commemorate, for example, "specific occurrences of the American Revolution" or "birthdays or inaugurations of revolutionary leaders turned presidents" (53). While Hebel points to keyed and framed commemorative practices with the clear purpose of commemoration, Welzer in his concept of 'social memory' extends the notion of memory as performance, or, rather, of performance as memory to the realm of unintentional acts of memory. While not speaking explicitly about performance yet nevertheless implying performatic practices, Welzer notes that

"[s]ocial memory" refers to everything which transports and communicates the past and interpretations of the past in a non-intentional manner. Four media of the social practice of forming the past can be distinguished:record, (moving) images, spaces, and direct interactions. Each refers to things which were not produced for the purpose of forming tradition, but which nonetheless transport history and shape the past in social contexts. (286)

In other words, everyday actions, habits, and behaviors as performative acts may constitute and perpetuate cultural memory/ies.

Seen from the perspective of performance studies then, cultural performances are performative in that they transmit cultural knowledge, be it 
implicit or explicit. Memory is performative in that it springs from cultural performances. Joseph Roach understands (cultural) performance-which is always corporeal and defined by the participation of bodies-as "coterminous with memory and history. As such, it participates in the transfer and continuity of knowledge: 'Performance genealogies draw on the idea of expressive movements as mnenemonic reserves, including patterned movements made and remembered by bodies [...]'" (Taylor 5 ; and Roach qtd. in Talyor 5 ). Introduced by Milton Singer in his collection of essays on Traditional India: Structure and Change in 1949, the concept of cultural performance remains central for performance studies' investigation of the perpetuating as well as interruptive potential of performance until today. Starting from a limited definitioncultural performance as clearly keyed and framed and mainly referring to nonartistic performances - cultural performance nowadays has reached a broader definition as situated anywhere on a continuum from particularly marked events to embedded everyday actions, from artistic and theatrical forms to rituals and events to behaviors and habits. In "Images and Reflections: Ritual, Drama, Carnival, Film, and the Spectacle in Cultural Performance," Victor Turner elaborates on Singer's initial idea of cultural performance:

Among the most salient 'concrete experiences' were what Singer found to be discriminable "units of observation" which he called "cultural performances." [...] The performances became for Singer 'the elementary constituents of the culture and the ultimate units of observation. Each one had a definitely limited time span, or at least a beginning and an end, an occasion of performance [...].' (23)

John McKenzie's more contemporary list of forms of cultural expression which may be labeled cultural performance illustrates the widening of the concept:

The field of cultural performance that has emerged over the last half century includes a wide variety of activities situated around the world. These include traditional and experimental theater; rituals and ceremonies; popular entertainments, such as parades and festivals; popular, classical, and experimental dance; avant-garde performance art; oral interpretations and storytelling; aesthetic practices found in everyday life, such as play and social interactions; political demonstrations and social movements. This list is open to additions, subtractions, and debate, but from it one can see that cultural performance is cultural in the widest sense of the term, stretching from "high" to "low" culture, though its most ardent proponents stress its countercultural aspects. (29) 
What has been an integral part of the concept of cultural performance since its inception is its ability to carry, transport, and perpetuate, "to express and communicate the content of [...] culture" (Turner, "Images and Reflections" 23). Cultural performance can be read as a medium of memory. Yet this medium does not simply transport stable cultural knowledge, but cultural performance serves as a gauge and evaluating force of cultural content. Turner uses the distinction between "reflective" and "reflexive" to explain this phenomenon:

I would agree with this, but only if it is realized that cultural performances are not simple reflector or expressions of culture or even of changing culture but may themselves be active agencies of change, representing the eye by which culture sees itself and the drawing board on which creative actors sketch out what they believe to be more apt or interesting "designs for living." As Barbara Babcock has written: "many cultural forms are not so much reflective as reflexive." Here the analogy is not with a mirror but rather with a reflexive verb "whose subject and direct object refer to the same person and thing." Performative reflexivity is a condition in which a sociocultural group, or its most perceptive members acting representatively, turn, bend or reflect back upon themselves, upon the relations, actions, symbols, meanings, codes, roles, statuses, social structures, ethical and legal rules, and other sociocultural components which make up their public "selves." (Turner, "Images and Reflections" 24)

In a similar vein, memory, as "the self-reflexive cultivation of the past" (De Cesari and Rigney 1 ) is always linked to a particularly present perspective on and appropriation of the past. The selection and manipulation of memory according to present needs and according to visions of the future may serve as a motor of change. While drawing on the past, memory is always also directed towards the future. The most prominent and obvious example is that of counter memorials and counter memory - a memory that deliberately tries to shape the future as a time different from the past. In a similar way, the reflexive nature of cultural performance leaves room for an enactment of either affirmation and perpetuation of cultural content or for the deliberate or accidental bringing about of gradual or radical, natural or critical development and change. In 200o, Jon McKenzie stresses the double potential of cultural performance. On the one hand, it may be effective in terms of "uphold[ing] social arrangements," "reaffirm[ing] existing structures," and offering a "possibility of conservation" (31). On the other hand, cultural performance is endowed with "transgressive or resistant potential" to "change" and "transform" "people and societies" (30, 31). John MacAloon summarizes the memory work cultural performance completes as well as the potential 
to enact change: Cultural performances "are occasions in which as a culture or society we reflect upon and define ourselves, dramatize our collective myths and history, present ourselves with alternatives, and eventually change in some ways while remaining the same in others" (introduction 1; my emphasis). Yet what happens when this "we" becomes more hybrid and/or complex in contact zones? What happens when the site of the memory performance is a transnational site? What happens when the location is characterized by cultural ideas that may or may not differ from the agent of memory?

Just like scholars of memory such as Nora or Halbwachs have stressed the importance of the spaces and platforms of memory — be it in the sense of its geographical and material or in the sense of its cultural, social, and political sitesscholars of performance such as Erika Fischer-Lichte insist on the importance of the very site of performance. The materiality of performance binds it in time and space. As soon as these factors change, the meaning of the performance (in poststructuralist fashion of an ever-evolving plurality of meanings) changes as well (Wirth 43, based on Foucault's Archaeology of Knowledge). Cultural performance and site, memory performance and space, become inseparable (see also Fischer-Lichte, Ästhetik 187, 200). Sounds, smells, objects, audiences become part of the performance. Yet the space of performance does not remain limited to the physical setting (Fischer-Lichte, Ästhetik 216). Cultural, social, political particularities - of the site and also those of the larger cultural, social, and historical space-likewise interact with the performance; more generally speaking, cultural performance "operate[s] within the highly coded system of a culture" (Carlson 44). Ultimately, memory performance and its site enter into a reciprocal and almost paradoxical connection of mutual influence. The performance of memory intersects with and thus impacts the meaning and identity of the site.

\section{Performing Trans/National Memory: From 9/11 to Independence Day}

Let us revisit the sites of the 9/11 memorial in Oberviechtach and the Grafenwöhr Training Area and extend our perspective beyond the archival dimension to the performatic dynamics. At the 9/11 memorial site in Oberviechtach, the dedication ceremony for a few moments in time overpowered the everyday meaning of the space as the park-like walkway from the gas station to the small downtowna walkway which may happen to feature WWI, WWII, and 9/11 memorials. For a brief moment in time, the $9 / 11$ memorial certainly dominated. Without the dedication performance, the space would have simply retained its everyday function and definition. Through the performance, it became the venue and the setting of 
9/11 commemoration (also see Fischer-Lichte, "Theater als Modell" 100). If performance has the power for cultural change, the cultural site of the performance may contribute to the change of the cultural content in performance. The dedication ceremony in Oberviechtach initiated the fusing of a Bavarian cultural space of WWI/WWII commemoration and local everyday routine with the commemoration of the victims of a terrorist attack set in a faraway u.s. surrounding. The Bavarian space transnationalized the commemoration of $9 / 11$ in Oberviechtach. Vice versa, the commemoration of the U.s. 'event' impacted and transnationalized the German/Bavarian space. What was initiated by the dedication ceremony continues to be performed by the presence of the memorial. If, as formulated above and for example argued by Turner or Fischer-Lichte, the larger cultural and historical space contributes to the constitution of meaning, the $9 / 11$ dedication ceremony did not only take place in a Oberviechtach setting, but in the larger context of German-American encounters in the former occupation zone. In that context, the dedication ceremony becomes a joint effort, "a site of negotiation" (Carlson 16) of German-American, or rather Bavarian-American, relations into the 21 st century. In Oberviechtach, the memorial in its seemingly stable materiality continues the memory work of the dedication ceremony, although in everchanging perceptions and although itself increasingly merging with its everyday surroundings. In Oberviechtach, the difference between dedication ceremony as memory performance and the memorial as site of memory may not be much. Yet the memory work of the dedication ceremony as cultural performance points to the centrality, power, and impetus of similar ephemeral memory performances that disappear and do not result in lasting memorials.

The 9/11 memorial in Oberviechtach may reveal itself quite openly as a transnational phenomenon. Yet even when performances of memory in the GermanAmerican contact zone of Bavaria take the shape of decidedly u.s. national cultural performances - strategically essentialistas these maybe - the performance cannot cease to interact with the German site. When the U.s. military base of Grafenwöhr celebrates Veteran's Day, the Fourth of July, or any other U.S. national holiday, it does so against the backdrop of, firstly, the German space, and, secondly, against the backdrop of the history of the Grafenwöhr Training Area as Bavarian, German Wehrmacht, and ultimately u.s./international military space. The displays and perpetuation of U.S. national narratives in holiday celebrations such as the 4th of July inevitably become negotiations of power in the former occupational zone. When the Bavarian Times, a U.s. Army-related newspaper, notes that "USAG Bavaria hosts the Fourth of July Hometown Celebration across its three communities to celebrate the birth of American independence with typical festivities ranging from casual gathering to barbecues and ending with fireworks" ("Fourth of July"), it announces a commemorative performance that affirms and perpetuates a particular version 
of and emphasis on American history. Yet the site of the performance unavoidably adds the dimension of international if not global power and presence and the particular history of wwII, liberation, and occupation. The event becomes even more complex - and ultimately transnationalized — when Germans are invited to participate in the U.s. national holiday. The blog section of the German-American Volksfest website notes: "Grafenwöhr. Die us-Armee Garnison Grafenwöhrlädt auch in diesem Jahr wieder ein, gemeinsam den Unabhängigkeitstag der Vereinigten Staaten von Amerika zu feiern. Die Veranstaltung findet am 4. Juli 2012 auf dem Paradeplatz in Grafenwöhr auf dem Truppenübungsplatz statt. Highlight ist um 22.30 Uhr ein Feuerwerk, das den Himmel in den Farben rot, weiß und blau erstrahlen lässt" (Matthias). ${ }^{8}$

Phrased from a performance studies perspective, Germans participating in 4th of July celebrations 'repeat' - simplisticly put-American traditions and behavior. The notion of repetition both in the Schechnerian sense of restored / twice-behaved behavior or in the Derridean sense of iteration can be seen as key to the effective power of performance (see also Derrida, "Signature, Event, Context"). Taylor locates the nexus of memory and performance in Schechner's idea: "Performances function as vital acts of transfer, transmitting social knowledge, memory, and a sense of identity through reiterated, or what Richard Schechner has called "twice-behaved behavior'" (2; see also 21). To Schechner, performances are "twice-behaved behaviors" (Performance Studies 28): "Restored behavior is living behavior treated as a film director treats a strip of film. These strips of behavior can be rearranged or reconstructed; they are independent of the causal systems (social, psychological, technological) that brought them into existence. They have a life of their own. The original 'truth' or 'source' of the behavior may be lost, ignored, or contradicted — even while this truth or source is apparently being honored and observed" (Schechner, Between Theater and Anthropology 35). In other words, strips of behavior can be "stored" (36) and "rearranged" (35) in settings that range from artistic stages to rituals and festivities to everyday actions and in contexts and by agents that are independent from the source (36). German participation in the 4 th of July celebrations in Grafenwöhr constitutes a varying repetition of a known or unknown original by agents with a different national/cultural background in a context that is somewhat original (American) and somewhat not (German). The potential of restored behavior lies in its combination of repetition and change. It is

8 Grafenwöhr. The Us Army Garrison Grafenwöhr is happy to once again invite you to its annual celebration of the U.S. Day of Independence. The event takes place on July 4, 2012, at the Grafenwöhr Training Area's parade ground. A highlight of the event will be a fireworks display at $10.30 \mathrm{pm}$, which will color the sky in red, white, and blue. 
always copy and creation at the same time. The joint German-American celebration of the 4th of July becomes a commemoration of an event that is neither fully American nor fully German; an event that may or may not be celebrated as a perpetuation of American narratives; an event that is transnational.

\section{Whose Memory Is It Anyway? Embodied Memory at the Volksfest}

Schechners term "restored behavior" points to a broad definition of performance and its inclusion of everyday actions, habits, and routines. The examples of memory performances discussed so far are clearly keyed and framed - events and festivities rather than behavior or everyday routines. Memory in the contact zone may, however, also take the shape of habits, behaviors, and practices that implicitly perpetuate cultural knowledge-embodied, behavioral, tacit knowledge. This idea takes us back to Taylor's distinction between the archive and the repertoire. "The repertoire," Taylor explains, "enacts embodied memory: performances, gestures, orality, movement, dance, singing — in short, all those acts usually thought of as ephemeral, nonreproducible knowledge" (20). "[C]ultural memory is an embodied practice" (Taylor 50 ). Taylor's term "repertoire" captures the paradoxical nature of an ephemeral form of expression, i.e. performance, that at the same time is supposed to enact something that lasts, i.e. memory. Taylor explicates that while "[...] individual instances of performances disappear from the repertoire" (20; my emphasis), as "reiterative behavior," performances do nevertheless not "disappear" (20) but are continued in subsequent repetitions. In Taylor's words: "Multiple forms of embodied acts are always present, though in a constant state of againness. They reconstitute themselves, transmitting communal memories, histories, and values from one group/generation to the next. Embodied and performed acts generate, record, and transmit knowledge" (21).

From these perspectives, the German-American Volksfest in Grafenwöhr constitutes a curious mixture of keyed and framed event (fig. 1). It happens at a particular time and space-usually in early August on the grounds of the Grafenwöhr Training Area—and it serves the clearly identifiable purpose of celebrating German-American friendship in the region and of commemorating past German-American encounters and a joint history. The Volksfest celebrated its 5oth anniversary in 2008 and in 2012 had a record of 80,000 visitors. In its set-up and dynamics, it is a concrete materialization and visualization of the cultural contact and exchange triggered by the military presence of the U.S. in the Upper Palatinate region. On these particular days, Germans cannot only enter the training area freely, but the location of the Volksfest turns into a space where Americans can tour cultural representations of their German environment and 
where Germans can tour cultural manifestations of the American military and cultural presence. Members of both nations and cultures can tour a space that represents their proximity in and around the military communities. It comes as no surprise then that the Volksfest displays both German and American military power-exhibits by the U.S. Army as well as by the German Army-to present the contact zone as a joint effort while at the same time emphasizing individual national strength. It exhibits both (stereotypical) German and (stereotypical) American food cultures and offers not only Bier and Bratwurst but also barbecues and burgers. The visual design engages in both Bavarian narratives and cultural clichés as well as in American narratives and cultural clichés (e.g. the Wild West, Oktoberfest scenes and Lederhosen, etc.) and thus uses the liminal space of the contact zone to perpetuate cultural narratives, however stereotypical they may be. Simultaneously, cultural power is enacted by claiming knowledge and a mastering of the respective 'other' culture: for instance, Germans selling Native American products produced in Germany or Americans in Bavarian clothing. Mirroring cultural encounters, the German-American Volksfest at the same time produces them. More than a mere representation, it is a participant and agent in cultural exchange as it, within the realms of the already existing contact zone, creates the space for specifically keyed and framed cultural encounters and for a spatial self-definition as open, multi-cultural, hybrid, and dynamic.

The Bavarian regional group The Flying Boots from the local town of Eschenbach presents a linedance show in the contact zone of the Volksfest. A German group with mostly German members thus engages in a cultural performance that originates in the U.S. and stages this performance in a GermanAmerican contact zone. Seen from Taylor's perspective of the repertoire, these German dancers repeat an American cultural form of expression and thereby perpetuate cultural memory in an embodied way. Yet whose cultural memory is this? Line dance as "an embodied praxis and episteme" (Taylor 17), as a cultural performance that enacts cultural memory, on the one hand, continues American cultural practice. Yet, on the other hand, in the case of the Flying Boots at the German-American Volksfest, the performers have changed in nationality and in space. It is different agents with different cultural contexts that produce the (variation of) the repetition and thus a new transnational (re)creation of the American embodied episteme which can no longer be attributed to one nation or culture. "Histories and trajectories become visible through performance, although recognizing the challenges and limits of decipherability remains a problem," Taylor claims (271). The Eschenbach line dancers make obvious the German-American historical and contemporary trajectories; their dance and the memory work it does, however, refuses clear categorization. They also direct our focus to the repertoire and the power of the 
repertoire for a study of memory - in transnational as well as in not so transnational contact zones. "It is imperative now," Taylor urges, and "overdue" to "pay attention to the repertoire" (27). She continues: "Part of what performance and performance studies allow us to do, then, is take seriously the repertoire of embodied practices as an important system of knowing and transmitting knowledge. The repertoire, on a very practical level, expands the traditional archive used by academic departments in the humanities (Taylor 26)." ${ }^{\prime}$

\section{Coda-What Is Memory Anyway?}

In 1945, American troops approached the region and triggered an intense period of German-American encounters. Today, Germans in the Bavarian city of Regensburg, for example, march towards Kullman's Diner to enjoy a burger, fries, coleslaw, and a coke. They engage in an activity that Walter Scott from Providence, Rhode Island, envisioned in 1872, when he created the first diner, or that Sam Kullman envisioned in 1927, when he founded the Kullman Dining Car Company. Thomas Feucht in collaboration with Kullman brought Kullman's Diner to Germany in 1999-literally from New Jersey to Bremerhaven. Kullman's decidedly perpetuates an American diner design; a glimpse into the menu confirms the American original. Kullman's opened in Regensburg in 2003. It has been a local favorite and a story of success ever since. Visitors to Kullman's accept and participate in the wellknown American practice of 'wait to be seated' before they engage in the-be it stereotypical or not-American embodied practice of eating a burger and thus contribute to the repertoire. Do they consciously perpetuate American cultural content and thus enact some sort of American memory? Some may do so, many may not. Even if they do not, they reiterate restored behavior, which may, to repeat Schechner, be "independent of the causal systems (social, psychological, technological) that brought them into existence. [...] The original 'truth' or 'source' of the behavior may be lost" (Between Theater and Anthropology 35). Just as "normalization has rendered [Butler's performativity of gender] invisible" (Taylor 5 ), the normalization of eating a Burger

9 Also see Bauridl and Wiegmink, "Toward an Integrative Model of Performance in Transnational American Studies," for a call for the interdisciplinary integration of cultural performance into the agenda of transnational American Studies. This endeavor is pursued by the DFG Research Network "Cultural Performance in Transnational American Studies" (Wiegmink and Bauridl). For calls for an awareness for performance studies (in American Studies), see especially Román; or Desmond; also see Wiegmink. 
in Regensburg may have rendered invisible the American character of eating a burger, i.e. the performance of (stereotypical) Americanness. If "cultural memory is an embodied practice" (Taylor 50 ), the customers at Kullman's consciously or unconsciously perform American memory work in the sense of perpetuating American cultural practice-a cultural practice that has lost, or not, its Americanness and gained transnationality. Regensburg is not Kullman's only German location, and there are further locations outside Bavaria. To discuss whether Kullman's is a result of the occupation and the continued American presence in at least some parts of Germany or whether it is just another instance of the often-cited globalization of American culture would be speculation. Eating a burger in the German-American contact zone of Bavaria, however, is a cultural performance that is always situated in a cultural, social, and political space that inevitably carries the history of liberation, occupation, and ongoing German-American encounters. Eating a burger in the German-American contact zone of Bavaria, then, is a cultural performance that enacts transnational (and supposedly) American memory in a landscape that is characterized by a myriad of post-wwII transnational / (heterogeneous) American / (heterogeneous) German memories and by ongoing German-American encounters that continue to be generated by the past history of liberation and occupation. Liberation was the starting point for the American presence in the region. Eating a burger continues not only American cultural memory, it continues the post-wwII German-American encounters of its setting and thus implicitly or explicitly commemorates German-American encounters in Bavaria in a transnational way.

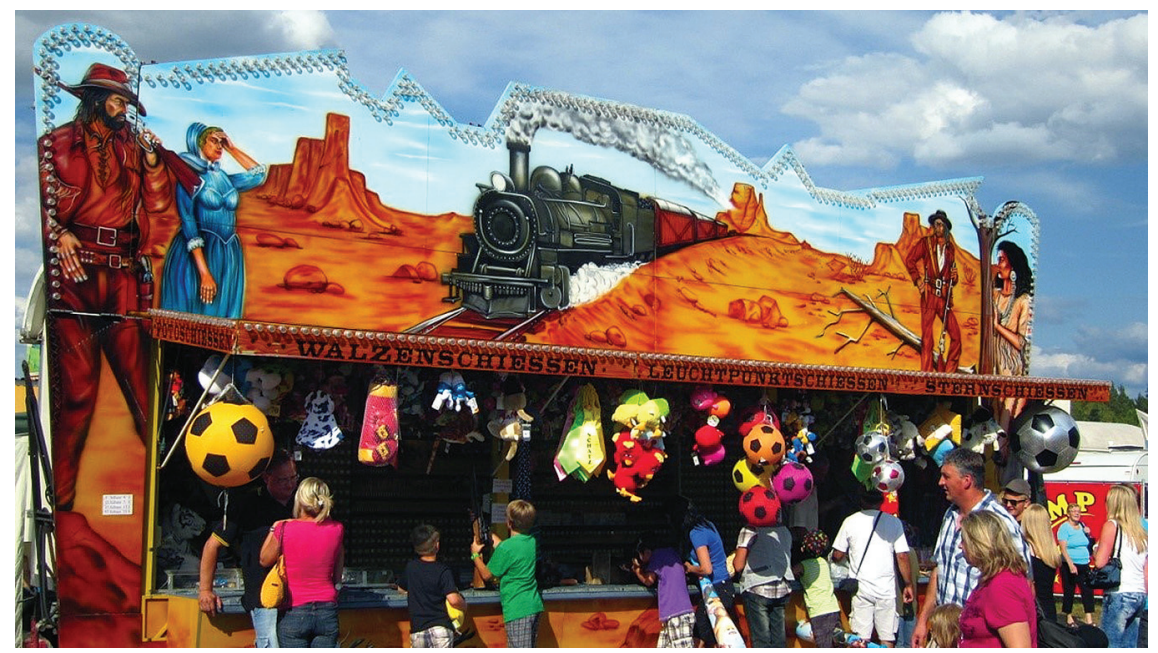

FIGURE 1 Elvis Exhibit. Burglengenfeld. 2012. PHOtOGRAPH By AUTHOR. 


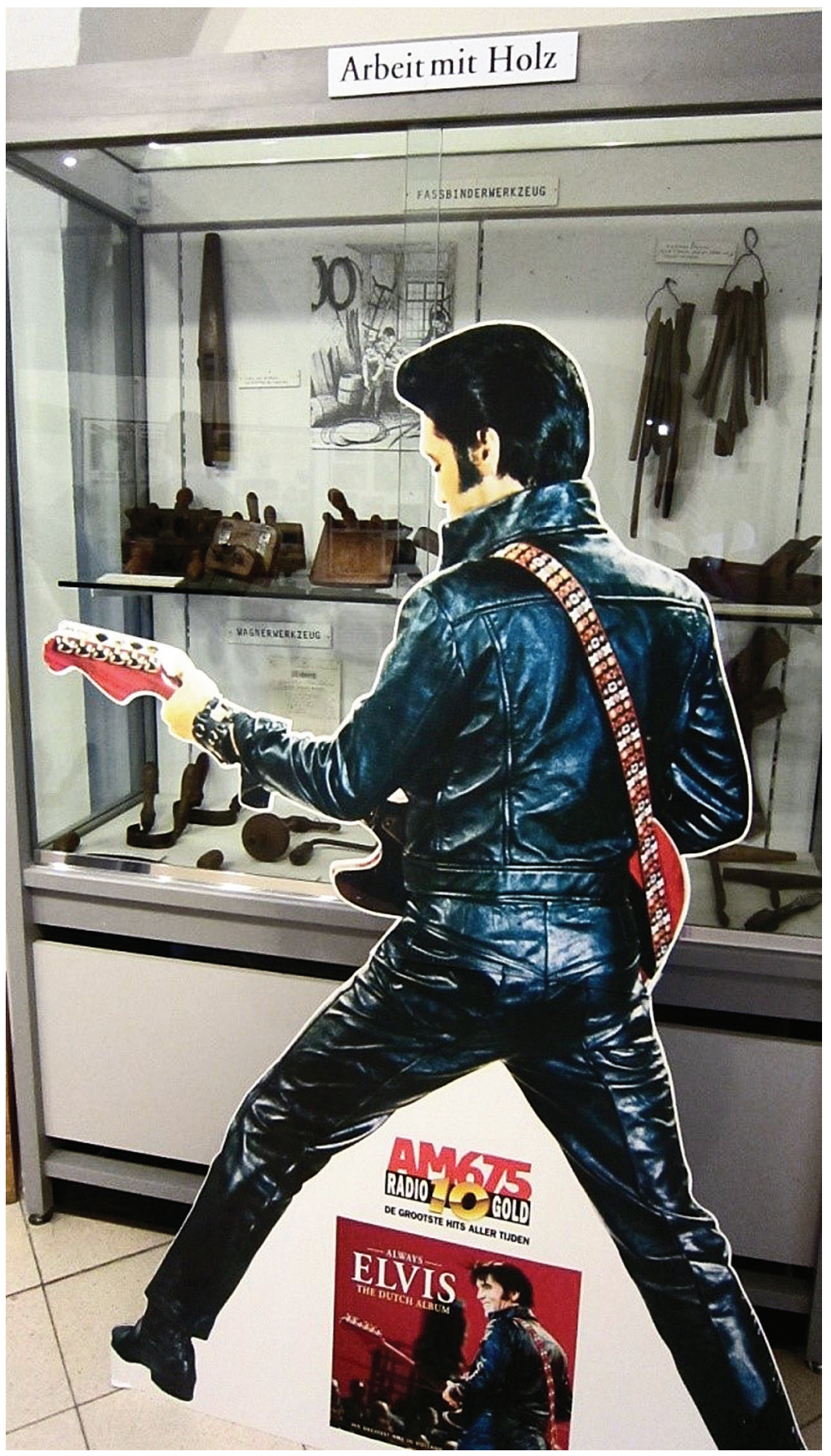

FIGURE 2 German-American Volksfest. Grafenwöhr, 2012. РнотоgRAPH By author. 


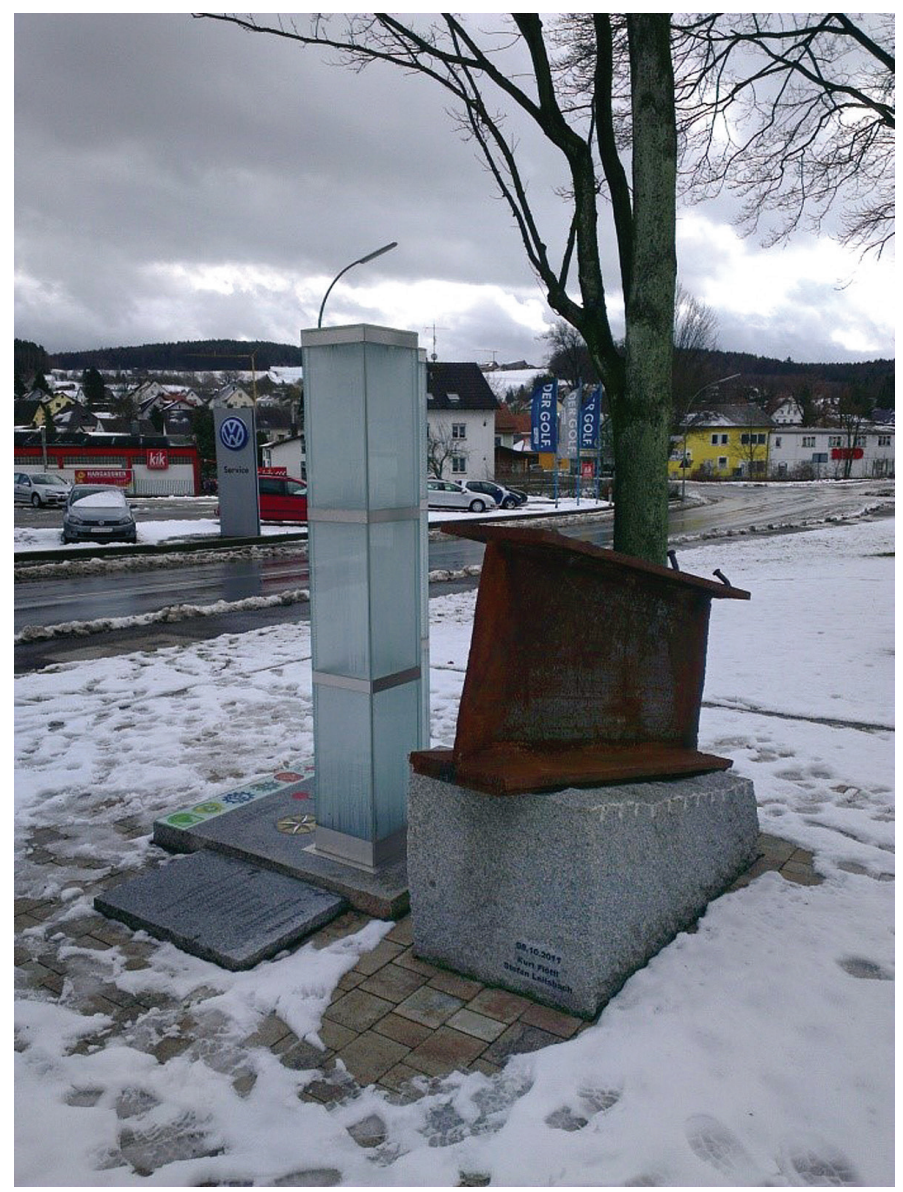

Figure 3 9/11 Memorial Oberviechtach, 2013. Photograph by aUthor.

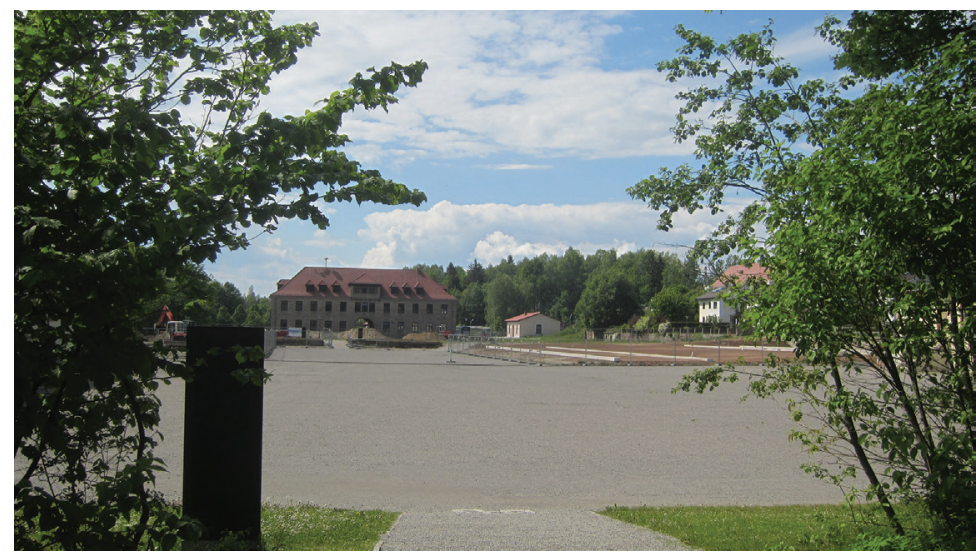

FIGURE 4 Flossenbürg, 2014. PHOTOGRAPH BY AUTHOR. 


\section{Bibliography}

"Fourth of July Hometown Celebration-Independence Day 2014." Editorial

Department in Garmisch, Grafenwoehr, Hohenfels, Vilseck. June 24, 2014. Bavarian Times. Accessed March 7, 2016. http://www.bavarian-times.com/fourth -of-july-hometown-celebration-independence-day-2014/2154.

Bauridl, Birgit M. 2016. "From Grafenwoehr to 'Graf': A Transnational American Region in Bavaria." In Critical Regionalism, edited by Klaus Lösch, Heike Paul, and Meike Zwingenberger; in coop. Jasmin Falk, Heidelberg: Winter, 103-30.

Bauridl, Birgit M., and Pia Wiegmink. 2015. "Toward an Integrative Model of Performance in Transnational American Studies." Amerikastudien / American Studies 6o.1, 157-68.

Bauridl, Birgit M., and Udo J. Hebel. 2014. "South Africa and the U.s. in Transnational American Studies: From Comparative Approaches toward Transangulation." Introduction. South Africa and the U.s. in Transnational American Studies. Ed. Bauridl and Hebel. Special Issuse of Amerikastudien / American Studies 59.4, 455-61.

Bishop, Karen Elizabeth. 2011. "The Propositional Logic of Mapping Transnational American Studies-A Response to 'Deep Maps': A Brief for Digital Palimpsest Mapping Projects." Journal of Transnational American Studies 3.2. Accessed August 10, 2012. http://escholarship.org/uc/item/9or5479j.

Carlson, Marvin. 1996/2004. Performance: A Critical Introduction. 2nd ed. London: Routledge.

De Cesari, Chiara, and Ann Rigney. 2014. "Introduction." Transnational Memory: Circulation, Articulation, Scales. Berlin: de Gruyter, 1-25.

Derrida, Jacques. 1977. "Signature, Event, Context." In Limited Inc, by Jacques Derrida, 1-23. Evanston, IL: Northwestern University Press.

Desmond, Jane C. 2001. "Making American Studies Dance." American Quarterly 53.3, 526-34.

Desmond, Jane. 2007. “Towards a Prismatic American Studies." Safundi 8.1, 5-13.

Erll, Astrid. 2010. "Cultural Memory Studies: An Introduction." In A Companion to Cultural Memory Studies, edited by Astrid Erll and Ansgar Nünning, Berlin: de Gruyter, 1-15.

Fischer-Lichte, Erika. 2004. Ästhetik des Performativen. Frankfurt/M.: Suhrkamp.

Fischer-Lichte, Erika. 2003. "Theater als Modell für eine Ästhetik des Performativen." In Performativität und Praxis, edited by Jens Kertscher and Dieter Mersch, München: Fink, 97-111.

Fishkin, Shelley Fisher. 2005. "Crossroads of Cultures: The Transnational Turn in American Studies." American Quarterly 57.1, 17-57.

Fishkin, Shelley Fisher. 2011. “'Deep Maps': A Brief for Digital Palimpsest Mapping Projects (DPMPs, or 'Deep Maps')." Journal of Transnational American 
Studies 3.2, n. pag. Accessed August 10, 2012. http://escholarship.org/uc/item/ $92 \mathrm{v} 100 \mathrm{to}$.

Gessner, Ingrid. 20o9. "Liberating Dachau: Transnational Negotiations of Holocaust Memory." In Transnational American Memories, edited by Udo J. Hebel, Berlin: de Gruyter, 243-65.

Gessner, Ingrid. 2015. "The Aesthetics of Remembering 9/11: Toward a Transnational Typology of Memorials." Journal of Transnational American Studies 6.1, n. pag. Accessed May 15, 2016. http://escholarship.org/uc/item/7pw6ko38.

Hebel, Udo J. 2008. “In Lieu of an Epilogue: Whereto American(ist) Memory Studies?” In The Merits of Memory: Concepts, Context, Debates, edited by Hans-Jürgen Grabbe and Sabine Schindler, Heidelberg: Winter, 389-95.

Hebel, Udo J. 2010. "Sites of Memory in U.S.-American Histories and Cultures." In A Companion to Cultural Memory Studies, edited by Astrid Erll and Ansgar Nünning, Berlin: de Gruyter, 47-6o.

Hebel, Udo J. 2003. "Introduction." In Sites of Memory in American Literatures and Cultures, edited by Udo. Hebel, Heidelberg: Winter, IX-XXXII.

Hebel, Udo J. 20o9. “Introduction.” In Transnational American Memories, edited by Udo J. Hebel. Berlin: de Gruyter, 1-9.

Ickstadt, Heinz. 2002. "American Studies in an Age of Globalization." American Quarterly 54.4, 543-62.

Lenz, Günter H. 2011 . "Toward a Politics of American Transcultural Studies: Discourses of Diaspora and Cosmopolitanism." In Re-Framing the Transnational Turn in American Studies, edited by Winfried Fluck, Donald E. Pease, and John Carlos Rowe, Hanover, NH: Dartmouth College Press, 391-425.

MacAloon, John J. 1984. "Introduction: Cultural Performance, Culture Theory." In Rite, Drama, Festival, Spectacle: Rehearsals toward a Theory of Cultural Performance, edited by MacAloon, Philadelphia, PA: Inst. for the Study of Human Issues, $1-15$.

Matthias. 201 2. "Amerikaner feiern Unabhängigkeitstag in Grafenwöhr-4. Juli 2012." Deutsch-amerikanisches Volksfest Grafenwöhr. Accessed March 7, 2016. http://www .volksfest-grafenwoehr.de/tag/unabhaengigkeitstag-grafenwoehr.

McKenzie, Jon. 2001. Perform Or Else: From Discipline to Performance. London: Routledge.

Pratt, Marie Louise. 1991. "The Arts of the Contact Zone." Profession 91, 33-40.

Pullman City: A Vibrant Western Town. 2011-2016. Accessed March 7, 2016. https://www.pullmancity.de/.

Román, David. 2005. Performance in America: Contemporary u.s. Culture and the Performing Arts. Durham, Nc: Duke University Press.

Rothberg, Michael. 2009. Multidirectional Memory: Remembering the Holocaust in the Age of Decolonization. Stanford: Stanford University Press. 
Schechner, Richard. 1985. Between Theater and Anthropology. Philadelphia: University of Pennsylvania Press.

Schechner, Richard. 2006. Performance Studies: An Introduction. 2nd ed. New York: Routledge.

Singer, Milton. 1959. "Preface." Traditional India: Structure and Change, edited by Milton Singer, Philadelphia, PA: American Folklore Society, IX-XXII.

Skriebeleit,Jörg. 2007. "KonzentrationslagerFlossenbürg, 1983-1945." KZ-Gedenkstätte Flossenbürg; 1999-2015. Accessed March 7, 2016. http://www.gedenkstaette -flossenbuerg.de.

Skriebeleit, Jörg. 2010. Erinnerungsort Flossenbürg:Akteure, Züsuren, Geschichtsbilder. 2009. 2nd ed. Göttingen: Wallstein.

Taylor, Diana. 2003. The Archive and the Repertoire: Performing Cultural Memory in the Americas. Durham, Nc: Duke University Press.

Traister, Bryce. 2010. "The Object of Study; or, Are We Being Transnational Yet?" Journal of Transnational American Studies 2.2, n. pag. Accessed March 7, 2016. http://escholarship.org/uc/item/864843hs.

Turner, Victor. 1988. The Anthropology of Performance. New York: PAJ, 21-32.

Welsch, Wolfgang. 1999. "Transculturality: The Puzzling Form of Cultures Today." In Spaces of Culture: City, Nation, World, edited by Mike Featherstone and Scott Lash, London: Sage, 194-213.

Welzer, Harald. 2010. "Communicative Memory." In A Companion to Cultural Memory Studies, edited by Astrid Erll and Ansgar Nünning, Berlin: de Gruyter, 285-98.

Wiegmink, Pia. 2011. Protest EnACTed: Activist Performance in the Contemporary United States. Heidelberg: Winter.

Wirth, Uwe. 2002. Performanz: Zwischen Sprachphilosophie und Kulturwissenschaften.

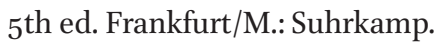

